\title{
EDITORIAL
}

\section{A GEOUSP MUDOU}

Ao completar 2 anos, a revista que nasceu com o objetivo precipuo de dar visibilidade às pesquisas realizadas pelos alunos da pósgraduaçáo em Geografia Humana do Departamento de Geografia da FFLCH-USP, agora ( sem abondonar esse objetivo inicial) abre suas páginas para todos os envolvidos na produção do conhecimento geográfico, privilegiando, no entanto, o universo do programa de Pós-graduação, deste Departamento. O compromisso da GEOUSP continua o mesmo, a veiculaçāo do conhecimento crítico produzido enquanto exercício de liberdade - que contemple a pluralidade do pensamento e dos caminhos abertos á pesquisa e capazes de estimular o debate Seu objetivo é aquele de abrir espaço para a divulgação da reflexão produzida a partir dos trabalhos de pesquisa, comprometidos com o desvendamento do mundo a partir ou através da Geografia.

Os artigos apresentados na primeira parte apresentam, mesclam assim, artigos escritos por alunos e professores do Departamento de Geografia da USP Armando Corrêa da Silva, Amália Inês Lemos e Amélia Luisa Damiani que tem em comum trazer para o debate uma perspectiva teórico metodológica. Nosso intúito é também trazer as reflexōes de ex - alunos deste programa e, a nosso convite a professora Lana Cavalcante, da Universidade Federal de Goiás, doutora pelo DG-USP, nos traz algumas idéias para enriquecer o debate sobre o ensino.

No seio destas transformações estamos inaugurando uma nova seção " Intercàmbio " para a publicação de artigos produzidos por professores estrangeiros com os quais os professores deste Departamento mantem relaçōes de pesquisa e intercâmbio acadèmico. O professor Paul Claval da Universidade de Paris IV- nos brindou com um artigo - Geografia e política especialmente redigido para este número. A GEOUSP presta, aqui, uma pequena homenagem ao querido colega e amigo José Estebanez - Universidade de Madrid -trazendo algumas de suas idéias a propósito de como pensar o espaço no contexto da globalização A outra novidade não se encontra nestas páginas, mas na tela do computador; em breve a GEOUSP também contará com uma versão eletrônica.

Na GEOUSP número 4 iniciamos um questionamento a propósito da avaliação realizada, por Comissão da CAPES, sobre o programa de Pós - graduação deste Departamento, com um artigo escrito a partir de um debate realizado entre o corpo docente deste Programa enquaanto o editorial, chamava atenção para os compromissos que estão por traz deste trabalho de avaliaçāo. Assim, tendo como mote o Relatório de Avaliação da CAPES iniciou-se no Departamento de Geografia da FFLCH- USP um debate sobre o processo de avaliação, só que inserido num contexto mais amplo e profundo : QUE PROPOSTA DE UNIVERSIDADE SUSTENTA ESTE TIPO DE AVALIÇÃO - realizada pela CAPES E QUE CONCEPÇÃO DE UNIVERSIDADE EMBASA NOSSO PROGRAMA DE PÓS -GRADUAÇĀO. É possivel a relizaçāo da pesquisa, na universidade, presa a parâmetros definidos fora do âmbito acadèmico - enquanto modelo fechado?

Em abril foi realizada uma mesa redonda com o intúito de estabelecer as bases deste debate. A conclusão é que uma tarefa se impõe; aquela de criar paràmetros de avaliaçáo dos programas de pós-graduaçào capazes de contemplar a pluralidade dos posições teórico- 
metodológicas que estão na base da constituiçào do pensamento geográfico brasileiro sem aprisionar a pesquisa num modelo hegemônico. A avaliação se impóe, nesse contexto, a partir de uma crítica séria e profunda de nosso trabaIho, de modo a fortalecer a pesquisa geográfica, enquanto trabalho acadèmico, que se propóe desvendar o mundo e pensar o futuro $O$ problema real não se resume a mudança de padrões de avaliação mas no debate aprofundado sobre os objetivos que a movem.
Na última semana de agosto a Pós-graduação estará realizando, no Departamento de Geografia da USP um seminário para discutir o projeto de universidade que embasaria a avaliação do trabalho acadèmico realizado na Universidade, capaz de balizar uma política ampla e séria que contemple as várias tendèncias e posturas surgidas ao longo da história Nesse sentido a GEOUSP abre espaço para veiculação deste debate de grande importảncia para a comunidade acadèmica.

Ana Fani Alessandri Carlos 